2285

G3

$C_{3}$

UC-NRLF

|| ||||||||||||||||||||||||

$\$ B \quad 31$ 0 $\$ 2$ 


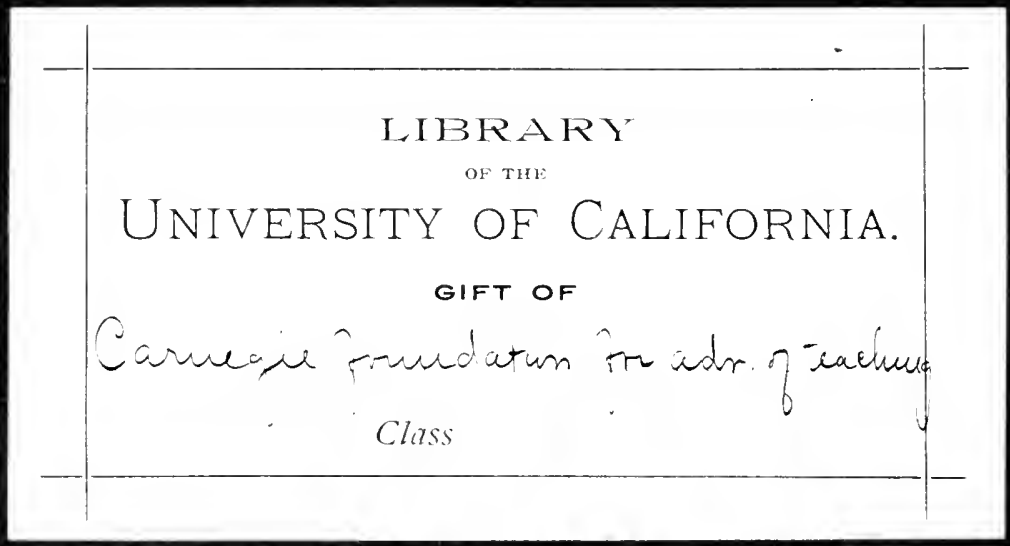




\section{THE CARNEGIE FOUNDATION}

\section{FOR THE ADVANCEMENT OF TEACHING}

$$
\frac{305 t}{3}
$$

A PLAN FOR AN EXOHANGE OF TEAOHERS

BETWEEN

PRUSSLA AND THE UNITED STATES 


\section{Digitized by the Internet Archive in 2007 with funding from Microsoft Corporation}




\section{THE CARNEGIE FOUNDATION \\ FOR THE ADVANCEMENT OF TEACHING}

A PLAN FOR AN EXCHANGE OF TEACHERS BETWEEN

PRUSSIA AND THE UNITED STATES

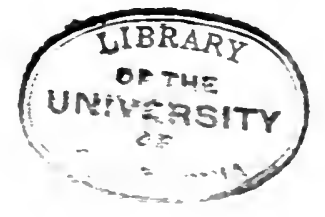

576 Fifth A venue

New York CITY

March, 1908 


$$
\begin{aligned}
& L B 22^{85} \\
& C_{3} C^{3}
\end{aligned}
$$




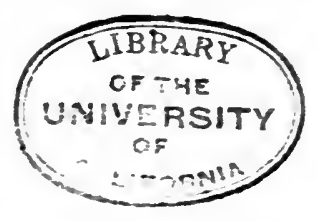

\section{PREFACE}

The following pages give in detail a plan for an exchange of teachers between Prussia and the United States, proposed by the Ministry of Instruction of that country and modeled after the system of exchanges now in operation between Prussia on the one hand and France and England on the other. The attention of American teachers and of presidents of colleges, universities, normal schools, superintendents of schools, and the heads of high schools is invited to the plan here presented for gaining an exchange of educational ideas in a most effective way.

The following American scholars have kindly consented to act with the president of the Foundation as a committee to consider the applications of such teachers or the recommendations of such heads of institutions as wish to take part in this exchange:

Professor Julius Sachs, Professor of Secondary Education, Teachers College, Columbia University;

Professor Calvin Thomas, Professor of the Germanic Languages and Literatures, Columbia University ;

Head Master James G. Croswell, Brearley School, New York.

In order that the details may be arranged with convenient despatch, it is earnestly requested that American institutions and American teachers who desire to coöperate in this exchange make known their wishes to the President of the Carnegie Foundation for the Advancement of Teaching at the earliest possible date.

Henry S. Pritchett.

March, 1908. 


\section{A PLA FOR AN EXCHANGE OF TEACHERS BETWEEN PRUSSIA AND THE UNITED STATES}

On behalf of the Department of Ecclesiastical Affairs, Instruction, and Medical Affairs of Prussia, Geheimer Ober-Regierungsrat, Dr. Karl Reinhardt, addressed the Carnegie Foundation for the Advancement of Teaching in the summer of 1907 and laid before it a plan for an exchange of teachers between Prussia and the United States. An exchange similar to the one proposed is now in effect between Prussia on the one side, and France and England on the other; and in view of the usefulness of this work, not only in the school systems of the respective countries, but also in furthering the better feeling and understanding of the countries, Dr. Reinhardt urged the extension of the plan to America. He requested that the Foundation act in an official capacity with the royal government of Prussia and that it arrange all details of the exchange for this side of the ocean.

Upon receipt of the communication from the Prussian Minister, the President of the Carnegie Foundation brought the matter to the attention of the Trustees, and at the meeting of the Trustees in November, 1907, it was voted that the President of the Foundation should undertake the supervision, on the American side, of the exchange with Prussia. This Bulletin is prepared, therefore, in order, first, to suggest the general nature and value of the system, and, second, to give the details by which it is to be put into operation. It is addressed especially to presidents of colleges, universities, and normal schools, to superintendents of schools and members of school boards, and to teachers who may wish to consider spending a year or a half year in Prussia under the conditions offered by the Prussian government.

\section{General Nature of the System}

The plan for this exchange of teachers is to effect a permanent arrangement by which teachers of the United States shall be assigned for a year or half year to schools in Prussia and vice versa. The instruction to be given in Prussia will be the teaching of English in a conversational way. It is not, however, necessary that the teacher should be a teacher of language in this country, but that he should be a cultured man able to conduct such exercises in an interesting manner.

The significance of the interchange of teachers between countries in Europe has greatly increased during the last two years. The immediate end gained by the exchange of teachers of language is the vitalizing of the instruction in foreign languages and the correction of defects in the system of instruction in one country or the other. But the indirect products of the exchange 
are far more important. A teacher transplanted for a year to a school in a foreign country has the opportunity to improve his whole view of educational methods. He returns to his regular work with increased efficiency and with freshened ability to teach.

By such an exchange students at an impressionable age learn of the social customs and gain the point of view of the people of the other country, and this under an arrangement which is stimulating and interesting in comparison with formal language study.

The exchange is therefore one that ministers not only to the improvement of the teaching of modern languages, but to general educational efficiency, to a broader understanding of other countries and a betterment of international relations.

From the point of view of the young, ambitious American teacher, the opportunity to spend a year in Prussia is attractive and should be considered in about the same way as a fellowship in a good American university. In either case the remuneration is slight. The American teacher who goes to Prussia for a year will receive from the Prussian government from one hundred to one hundred and ten marks a month (\$25 to \$27.50). It is estimated that this is equivalent to about $\$ 40$ to $\$ 45$ a month in a small town in the United States, and that it will meet the actual living expenses of the teacher during the year.

The remuneration is a secondary consideration. Teachers, especially those who are now serving their apprenticeships as scholars or fellows in colleges and universities, preparing themselves for the profession of teaching, will recognize the benefit which a year of study and conversational teaching in Prussia would bring them. The opportunity is virtually that of a travelling fellowship. The teachers have the right to attend instruction in all classes of the institution so far as it is beneficial to their work. Many teachers in the United States who consider the plan may not welcome the idea that they are to remain at one particular institution during their official connection with the school system in Prussia; and that, further, they are under the direct guidance of the director of the institution to which they are assigned. These restrictions, however, have their advantages. The privilege of becoming acquainted with the school system of Germany in all its working details and the fact that this privilege is accorded the visiting teachers under most dignified and agreeable circumstances are worthy of emphasis. The director of an institution to which a teacher is assigned will, with his colleagues, take a personal interest in introducing the teacher into the social life of the community. Good fellowship is extended to him, and with this the opportunity to gain an intimate knowledge of German ideals in teaching and to observe German methods in practice. In the United States such an opportunity is usually accorded a visitor who gives evidence of sincerity in his desire for the privilege, but in Prussia the privilege is rarely granted to any one except through formal application to the Royal Minister of Instruction.

In no case are teachers to take part in the formal instruction of the institution which they visit. They do not do the work, or even part of the work, 
of a regular teacher. 'This would impose too heavy a burden upon the visitors and would render their relationship with the students too didactic. The plan is for the visiting teacher to teach conversation in his own language in an informal manner for not more than two hours cach day, his classes being small groups of upper classmen who wish to perfect themselves in the language of the teacher. The students and the teacher discuss the manners and customs of the teacher's home, the school arrangements, the family life, the conditions of public life, the social usages, etc. Work of this nature will not interfere with the tcacher's leisure for study and observation, and for short trips to communities other than his own.

\section{Details of the System}

All matters of business connected with the exchange of teachers are transacted either through the Prussian Minister, whose address is Berlin W, 64, Wilhelmstrasse 68, or through the Carnegie Foundation for the Advancement of Teaching, $5 \% 6$ Fifth Avenue, New York City. All communications from those interested in the matter in the United States should be addressed to the President of the Carnegie Foundation for the Advancement of Teaching.

All applications from institutions for teachers from Prussia and for appointments of individuals to go to Prussia should be filed at the office of the Foundation not later than June 15, to go into effect in October. In making application a teacher should give his full name, address, date and place of birth, citizenship, religious faith, academic preparation for teaching and information concerning his fitness for the work, and preference in regard to situation in Prussia. Formal application blanks for this purpose may be had upon request from the offices of the Foundation.

The candidate for appointment to a position in Prussia should be a graduate of a college which requires for admission the usual four-year high school course. He must have been for at least one year a teacher, though not necessarily a teacher of languages, and must have reasonable facility in the German language. The teacher who goes to Prussia will enter a gymnasium or a realgymnasium. His work will be the informal teaching of the English language by means of conversation. As stated in the general discussion, the remuneration is one hundred to one hundred and ten marks a month paid by the Prussian government in monthly installments.

A teacher coming to the United States from Prussia may enter a college or a high school of good standing. His work, similar to that of the American teacher assigned to a post in Prussia, will be the teaching of the German language by means of conversation. The Prussian teacher for appointment in the United States must be a graduate of a German university and must have served for at least a year as a probationary teacher under the director of a gymnasium.

Any educational institution or city school board which makes application for a Prussian teacher must agree to pay the visiting teacher a sufficient sum to meet modest living expenses such as board, room, laundry, etc. In no case 
should this amount be less than the monthly allowance which the Prussian government pays to an American teacher in Prussia. An amount of approximately fifty dollars a month for a period of eight months will usually meet the requirement. The amount will vary according to location.

Many colleges, universities and normal schools which have departments of German will probably be glad not only to select a representative to go to Prussia, but also to receive in return a Prussian teacher who would doubtless stimulate a new interest in the work of the department. It is not necessary, however, that an institution which receives a Prussian teacher should also nominate a teacher to go to Prussia; nor that if an institution sends a teacher to Prussia, it receive a foreign teacher in return.

The Prussian government pays all the necessary travelling expenses of the teachers selected to come to America. While many of the American teachers will probably be willing to pay their own travelling expenses to Prussia, it is hoped that institutions which nominate the individual teacher will also pay the transportation to Prussia, thus making the appointment one of distinction and honor as well as an educational opportunity.

All appointments are made either for one academic year or for one-half of the academic year. The year begins at Easter and is divided into two terms, the second term beginning about October 1. There are generally two weeks vacation at Easter, two weeks at Christmas, one week at Whitsuntide, and about four weeks in July or August according to the arrangement of the Ministry.

In accepting an appointment from either country, teachers pledge themselves not to publish anything concerning the institutions with which they are connected except with the permission of the proper authorities. This restriction is a nominal one. It is understood that there will be no objection to any serious and well-informed publication on the part of the visiting teacher.

At the present time, women are not eligible to appointments as exchange teachers with Prussia.

American teachers who take these appointments are expected to render a report at the end of their service to the President of the Carnegie Foundation concerning such matters as seem to them important or to have educational value.

The Carnegie Foundation assumes no financial responsibility in acting as an agent in this exchange of teachers.

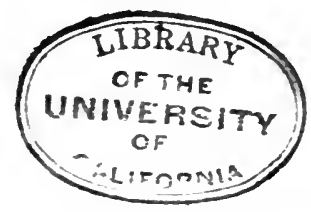




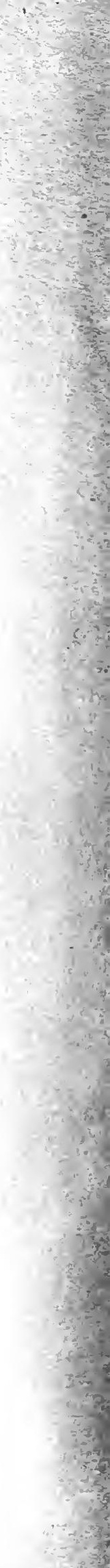




\section{UNIVERSITY OF CALIFORNIA LIBRARY BERKELEY}

THIS BOOK IS DUE ON THE LAST DATE STAMPED BEIOW

Books not returned on time are subject to a fine of $50 \mathrm{c}$ per volume after the third day overdue, increasing to $\$ 1.00$ per volume after the sixth day. Bookg not in demand may be renewed if application is made before expiration of loan period.

Ang î 1918 


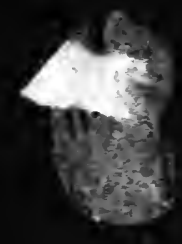

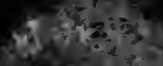


